\title{
On the Problem of "Illiteracy" in the Contemporary Knowledge Society
}

'Slavomír Gálik

\author{
2Sabína Gáliková Tolnaiová \\ ${ }^{1}$ Professor, University of Ss. Cyril and Methodius, Faculty of Mass Media Communication \\ Nám. J. Herdu 2, 91701, Trnava, Slovak Republic, s_galik@yahoo.com \\ ${ }^{2}$ Doctor, University of Ss. Cyril and Methodius, Faculty of Mass Media Communication \\ Nám. J. Herdu 2, 91701, Trnava, Slovak Republic, sgalikovatolnaiova@gmail.com
}

\section{Doi:10.5901/mjss.2015.v6n6s4p230}

\begin{abstract}
The authors of this paper study a paradox in the contemporary knowledge society - fall in level of erudition that is here despite the evident information and technology expansion. They blame the Internet to be the cause of this which, despite a number of positives such as possibility for fast communication, search for information, entertainment and similar also brings some risks. The authors describe six risks that they believe present bad influence on contemporary erudition: 1st reduction of knowledge to mere atomised information; 2nd reduction of knowledge to only expressible and useful knowledge; 3rd fixation to just results; 4th weakening in abstract, linear and logical thinking; 5th weakening of the connection to the past and future; 6th acceleration and cumulation in information flow. The authors state that it is only support of real erudition, bound with understanding and wisdom, that can eliminate these risks, generated by communication on the Internet.
\end{abstract}

Keywords: Information, knowledge, erudition, wisdom, Internet, knowledge society.

\section{Introduction}

Modern society is characterised as information, or knowledge society, bound with change from industrial society to postindustrial society. D. Bell (1973, p. 343) understood post-industrial society as society based on services and information, hence as information society. F. Machlup and especially P. F. Drucker (1994, p. 268) further studied the term knowledge, or knowledge worker and industry. These terms started spreading in the $60 \mathrm{~s}$ and $70 \mathrm{~s}$, but particularly under the influence of the Internet in the 90s. Sudden development of information technologies, chiefly the Internet, greatly promoted emerging of optimistic scenarios concerning economical and erudition rise in the society. This trend, though not so optimistic thanks to the fiasco and revision of the Lebanon agreement from 2005, is still present. The idea that technological development should bring also development in culture and society, including knowledge society, still lingers here. Specialists that study the field of education, for example K. P. Liessmann, M. Bauerlein, M. Spitzer, N, Carr, E. Višňovský and others, agree that something is wrong in our education process or education system. K. P. Liessmann (2010, p. 11) even speaks of "ignorance" in the modern knowledge society, Bauerlein (2010, p. 19) about the most stupid generation, Spitzer (2014, p. 58) of spreading digital dementia, Carr (2010, p. 42) of frivolous thinking and E. Višňovský (2014, p. 38) speaks, in the context of university education, about the general crisis in university education system. This hints our modern knowledge society encounters some serious mistakes that are dealt with inadequately.

The goal of this paper is to examine in detail why the level of erudition is decreasing, despite the fact that there is an evident information and technological development. We consequently analyse the main causes for this decay and suggest possible solution of this problem. The authors will study this problem from the position of techno-media determinism, from the technology's determining influence on cultural changes, which is now presented by information technology, especially the Internet.

\section{Media Influence on Human and Culture}

A well-know representative of cultural anthropology and founder of culturology L. A. White (Soukup, 2004, p. 472) states that "the determining role in the system of culture is taken by technological subsystem. It determines form and content of the remaining components of the system." So it is not the ideas but new technologies that steer the further advance in the culture. Culture can also reflect some effect on the media, but this effect is not determining. What applies to technologies 
is even truer in case of communication technologies, such as media. M. McLuhan (2009, p. $20-35)$, as one of the most influential media theoreticians, believed that media represent human extensions, hence media do not only have cause because they are carriers of the content, but also because they represent a technological structure. T. Tökölyová and A. Modrzejewski (2013, p. 39) state that media affect our thinking, our imagination and shape our understanding of the world. J. Lohisse $(2003$, p. 167) also claims "(media) tool is much more than just mere instrument. From the very beginning it creates social structures, interferes with thinking, steers imagination, represents a condition for understanding the world."

Lohisse (2003, p. 12), similarly to S. Harnad (1991, p. 39), distinguish four revolutionary types of media: speech, writing, press and electronic media (the Internet). They all have their own semiotics that created conditions for birth of cultural epochs - the epoch of speech, writing, mass and shapelessness. Understanding of influence that the predecessor media had can help us understand better also the influence of the modern type of dominant media, the Internet:

Speech is the first and natural communication form of human. Articulate words are created in the vocal cords and spread in the sound waves through the space. This sound "scene" of phonemes pulls those who communicate into a common communication space and time that will favour the gestalt understanding - unity of the world, though structured inside, cyclic time and global understanding of society. Speech in the pre-literature societies is not understood to be merely a mean of communication, but as a magical phenomenon that has a direct impact on reality.

Writing breaks up the unity of the speech. It is given by the very technological structure of writing, especially the phonetic one, which is a linear succession of visual symbols. Reading and writing characters supports perspective vision, discipline of thinking in precision of expressing and distinguishing individual meanings, a greater distance from the issues and thereafter also abstract thinking. In the collective mentality of the epoch of writing, the general, cyclic idea of time was violated and replaced by the idea of linear time.

On one hand, press smoothly replaced the era of manuscripts, but on the other hand it also transformed it significantly. The principle of press, unlike handwriting, was based on a new technology of producing the symbols, which were standardised and separated from the author. Furthermore, it enabled fast making of a large number of identical copies, which influenced homogenisation of the culture and consequently started the existence of a mass society. In the perspective of epistemology, press had a great effect on subject-object perception of knowledge. Similar to the way author's work spread without his own effort, also knowledge, which wants to be objective, must be independent from the subject. Objective knowledge was understood to be mechanistic and mathematically expressible.

The Internet, according to Harnad (1991, p. 39), is the fourth revolutionary medium and we notice its rapid development in the 90s. This medium was essential in birth of information or knowledge society. The nature of the Internet, we believe, is in its non-linear, net-like interconnection of communication technologies. We think the idea of a "net," which is even in the name - "Internet" (inter and net), is the best to describe the nature of new technologies that offer non-linear communication. However, we need to realise the difference between our idea of "net" 1 and real net-like communication. The real Internet grid lies beyond the limits of our imagination and we can only come close to it using certain symbolic concepts and descriptions. This net is three-dimensional and creates what we call cyberspace, in which information gets interconnected multilaterally. Apart from having a net-structure, the Internet is characterised by the possibility for active and fast communication of information of especially iconic (image) character. Basing on these approaches, we could define the Internet as an intermediate agent and medium that allows us communicate - actively and almost instantly - ideas of iconic (image-based) character.

Using the Internet, similarly to the previous sorts of media, will greatly influence our cognitive abilities and, generally, the very culture and society itself. Long-term usage can bring a change into the strategy of our thinking, which will need to adapt to the basic structure of the Internet. J. Bystrický $(2008$, p. 19) says on this: „with increasing usage of technology, we also employ a different approach in thinking, not by changing the qualities of our own dispositions, but by changing the strategies of their usage". K. Leidlmair (1999, p. 19), in reference to Heim, also states that using of computer technologies, especially hypertext structure of the Internet, changes radically our everyday thinking. Contact with such communication technology will undoubtedly have a great impact on human's cognitive abilities and this influence, as J. Lohisse (2003, p. 176) believes, will not be present only at the time we use this medium, its influence will be spreading, it will simply be encoded into our usual thinking process, so it will eventually change the whole society and culture. It is for this reason why the level or our erudition will be influenced by the changes that are brought by using the Internet.

\footnotetext{
${ }^{1}$ The idea of "net" may evoke non-linear communication that is realised in two dimensions, that is on a flat surface.
} 


\section{Internet's Influence on Contemporary Illiteracy - on Some Risks}

The internet is a modern par excellence phenomenon, since it represents a unique communication tool, fast search for information, job vacancies, entertainment and similar. However, it also brings some dangers that are less reflected and that, as we believe, contribute to fall in present erudition. We think they are these dangers:

\subsection{Reduction of Knowledge to Mere Atomised Information without Further Relation to Erudition and Wisdom}

Information technologies, for example also the Internet, use data that is possible to be quantified. Data that flows through a computer interface into "human world" becomes information. However, the difference between data and information is significant. For example, J. Cejpek (2005, p. 33) says on this: "In this respect, computers are not machines to process information, but process data. We may only speak about information when the receiver is a human being, with his consciousness - when he starts to perceive text, image or sound output of the computer or printer" We do not understand information to be algorithmic units - data, but context-based data. Understanding of information is based on semiotic rules in the grid of positions and oppositions Thus, information will never be a piece of atomised unit, it will always be context-based, otherwise we would not understand it. Influenced by computer technologies and the Internet, we sometimes tend to count and atomise individual bits of information.

Cejpek (2005, p. 23) further warns that information is not knowledge yet. "Thus mere information is not knowledge, it only creates basic condition for knowledge." He refers to philosopher J. Patočka, who stated: "the concept of information cannot possibly explain the concept of understanding and knowledge. ...." Information is still relatively atomised, object-bound, fragmented and therefore countable and disarranged. Knowledge however is a higher level that arranges, synthesizes information into meaningful units. M. Růžička (1993, p. 15) for example understands knowledge (information quality in his approach) as information that reorganizes and changes our experience, knowledge horizon and enters into co-existence of communicating entities.

Knowledge alone, cross-referred to just itself, is not enough since it could slip into "atomised models," similarly to information. Individual bits of knowledge therefore need to join each other, synthesize, which is represented by various levels of education. Education system is designed to help us manage certain sort of knowledge. M. Potůček (2003, p. 51) identifies this knowledge-exceeding level as understanding: "Understanding as a further level of knowledge does not only offer an answer for the question of how, but also the question of why. Knowledge cannot be "memorised" or "tried out" and to understand means to comprehend the principles. People who understand can, basing on reasoning (and not just experiment) synthesize available information and knowledge and thus create new knowledge." We would add that without education, or certain kind of education, we could neither understand nor handle knowledge. The fifth, most advanced degree of knowledge is, according to Potǔček (2003, p. 51), in wisdom: "Wisdom then represents the greatest degree of knowledge. It includes understanding of the general relations between various, even very remote occurrences, knowledge of gaining understanding and experience-proven system of values." Wisdom then is the total of theory and practice, into which we can add the complex experience of man with value system and ethical actions.

We can summarise now that the modern knowledge society should not only be oriented to atomised knowledge and its economisation, but understanding (education) and especially wisdom. Reaching the state of being wise should be the goal of both a knowledge society and process of education.

\section{2 reduction of knowledge to only expressible and useful knowledge.}

Another mistake in the knowledge society that spreads into education is reducing information to only expressible and useful knowledge. As we have already stated above, terms such as information and education are context-based and furthermore, this context does not necessarily have to be fully conscious. Part of the meanings of information or knowledge always lies partially in dim region of consciousness (or unconsciousness). This inexpressible knowledge is also known as tacit knowledge. F. Murgaš (2011, p. 5) characterises tacit knowledge as "non-verbalized and usually unconscious. Here, verbalising is difficult, intuition ability and creativity is visible in communicating tacit knowledge". A wise and educated man commands a great deal of tacit knowledge that manifests indirectly, for example in creativity, virtue of orientation, systematic work with knowledge and similar. Effect of tacit knowledge is obvious in the already mentioned intuition that we can understand as non-mediated and sudden knowledge. Yet, this kind of knowledge usually comes after pre-existing accumulated knowledge and experience. The sudden idea synthesis - new knowledge - is manifestation of the preceding accumulated knowledge that we cannot consciously access. This intuitive knowledge lies in the highest levels of the so-called innovations and is usually identified by new and unexpected way of dealing with a 
problem. Eliminating of tacit knowledge means eliminating intuition and creativity. Therefore reducing information to just expressible and useful correlate is highly risky for education in a knowledge society.

\section{3 fixation to results rather than conditions of knowing - in human as a psychophysical and moral being.}

In the modern knowledge society and consequently also in education, there is a massive preference for outcome of knowing. This outcome can be reached by further preference approach, which is represented by critical thinking. Critical thinking (Šándorová, 2013, p. 9) is usually understood to by rationally, creatively and argumentatively competent thinking. Often, there is misconception that goes along with this and supposes that knew knowledge should be generated automatically, through critical thinking. However, it omits conditions for critical thinking that set high requirements on the subject of learning. These criteria, as we have already mentioned, can only be met by a wise and educated (with extensive tacit knowledge) person. In this case, mere intellect is not sufficient; we need a whole complex of mental, psychic and physical dispositions with such a value system that puts the good to the highest of positions.

Basing on this, we state that another risk in a knowledge society is in isolate emphasizing of the outcome of knowledge without mentioning the conditions for such knowledge and relating to the learning subject alone.

\section{4 weakening in abstract, linear and logical thinking.}

In communication on the Internet, we see some fundamental structural changes in human's thinking. The most visible change is in change from linear to net-like interconnection of information. We can describe this shifting as "disintegration of linear code" which we can see in the change in thinking and change of the idea of time. The nature of net-based connections of information can be explained by the term rhizomorph (rhizome - botanical term that describes a threadlike structure or roots) that is quite well-established in philosophical and media discourses. This term was first used before the Internet by G. Deleuze and F. Guattari (2010, p. 30), who describe it as follows: "unlike trees or their root structures, a rhizome connects any given point with another any given point, while each of the symbols does not provide a link to other symbols of the same kind; it introduces very different regimes of symbols, even non-symbol states." Similarly, U. Eco (2012, p. 60) followed the concept of rhizome and put it aside the previous tree-like (arborescent) thinking. The idea of a tree in, let us say, Middle Ages thinking (arbor porphyriana) represented the order of hierarchybased and logical thinking from the essence of being to its marginal manifestations. Rhizomatic thinking, on the contrary, is non-systematic, fragmentary, net-like, with no beginning and no end. Eco $(2012$, p. $60-61)$ for instance claims that rhizome justifies and supports even contradictions, since rhizome creates non-linear loop processes. He even states that "to think means advance blindly in the rhizome, follow just assumptions." The Internet, which is characteristic for its hypertext or let us say rhizomatic interconnection of information, will not support abstract, linear and logical thinking. ${ }^{2}$

Weakening in abstract, linear and logical thinking also greatly endangers erudition level in contemporary knowledge society.

\section{5 weakening of the connection to the past and future and strengthening of the present.}

Along with disintegration of linear thinking comes also disintegration of the idea of linear time. In communication on the Internet, there are no physical footholds that would enable measuring the time. Time becomes present, simultaneous on the Internet. Hypertext non-linear interconnection of information, which has no beginning and no end, also advocates synchrony of time. Such perception and experience of time then affects understanding of culture, which is no longer set on tradition but becomes contemporary by the means of hypertext. P. Rankov (2006, p. 26) says: "in a net, culture spreads only horizontally, simultaneously, merely spatially and time means nothing. ... Information transfer in time is nowadays merely a side-effect of the net-based culture." Strengthening of the present can on the other hand lead to denying the past (but also future) with all that the past contains such as tradition, religion, idea of nation and the like. According to M. Bauerlein (2010, p. 182), who did researches in erudition in American youth, he came to a conclusion

\footnotetext{
${ }^{2}$ Desultory and systemless thinking will be favoured by dominancy of images on the Internet; these imply entertainment and frivolous attitude. H. Pravdová (2009, p. 294) states: "Though entertainment has been one of the characteristic characteristics of human culture since it started its existence, individual member of this society has never faced as many delights as we see now." The image, which is more soaked with information than text, according to Solik (2014, p. 213), also influences emotions and frame of mind, which is the reason why iconic communication basically implies fun.
} 
that knowledge that somehow incorporates the past is declining year by year, which presents a risk for the future progress in democracy and functioning of the state. This loss of sense of the past and future can mean a great risk for a knowledge society.

\section{6 acceleration and cumulation in information flow.}

Communication on the Internet is getting close to the speed of light, so it is almost immediate for the user. High communication speed on the Internet will be speeding up all our aspects of life, because we use the Internet to learn, communicate, work, shop and do business. The high speed of communication and geometric growth of information on the Internet will cause troubles in processing of information timely. Cumulation of information, as T. H. Eriksen notices, will lead to simplification and imperfections, information noise and fading in the difference between working time and spare time. Eriksen (2009, p. 77) says "Some of the consequences of its usage can already be seen now: it shortens distances and fills the current moment with information. Similarly to cars and jet planes, new information technologies lead to acceleration and require further acceleration until the time is close to zero." Possibility for acceleration of information flow and its accumulation is not unlimited, because there are certain biological and psychological limitations in human, therefore it can mean a great danger for knowledge society.

Basing on the above-mentioned analyses, we can deduce that it is likely for the Internet to favour non-linear, netlike thinking that leads to frivolous attitude. With linear thinking, we may develop an idea step by step, we can go deeper into the object. Frivolous attitude however misses this possibility. Acceleration in communication speed, cumulation of information and shortening in time available for real processing will support frivolous thinking. Similarly, this will also be advocated by dominance of images on the Internet and communication which happens in the present and which represses sense of linear succession and consequently linear time and sense of history approach. This means that noncritical acceptance of the Internet may mean a great risk for level of erudition in contemporary knowledge society.

\section{Conclusion}

New information technologies, especially the Internet, have always had a great impact on forming of information society, or its extension, knowledge society. The Internet and chiefly communication through the Internet brings along some possibilities, but also risks. In this paper we spoke about six risks that, as we believe, have a negative influence on contemporary erudition. They are the following risks: $1^{\text {st }}$ - reduction of knowledge to mere atomised information without further relation to erudition and wisdom; $2^{\text {nd }}-$ reduction of knowledge to only expressible and useful; $3^{\text {rd }}-$ fixation to results rather than conditions of knowing - in human as a psychophysical and moral being; $4^{\text {th }}$ - weakening in abstract, linear and logical thinking; $5^{\text {th }}$ - weakening of the connection to the past and future and strengthening of the present; $6^{\text {th }}$ acceleration and cumulation in information flow.

These approaches and ways of communication and processing information on the Internet directly support Liessman's concept of "capitalisation of the spirit," hence very direct connection between knowledge and economy. It is knowledge, objectified, counted in fragments and able to be processed fast, that economy favours. In this point, the principle of economic growth is in opposition with classical erudition that relies on tacit knowledge, contextuality and wisdom. Erudition and wisdom however mean the greatest potential in the society, therefore if erudition gets fully controlled by economy, it will degrade and eventually fight against economy itself. We gave and example of incorrect understanding of information and knowledge society - fiasco of Lisbon strategy. In case of Slovakia, we can be reminded of the government "confession" back in 2004 about badly invested billions of Slovak crowns in development of information society. ${ }^{3}$

Only real erudition combined with a broader understanding and wisdom can fight economisation or capitalisation of education, because, as Spitzer (2014, p. 58) notices: "education brings liberation - liberation from the number of temptations, for he, who is educated, can employ a critical approach to himself and his surroundings, he is not a helpless puppet that anybody can play with, he is capable of dealing with issues directly." If we said that fall in erudition level is bound to the influence of the Internet, then it is also media education that could help raise erudition level. This media

${ }^{3}$ In a document of Ministry of Education of the Slovak Republic, named "Strategy of Informatisation of Society in the Conditions of the Slovak Republic and Action Plan" from 2004, we can find this concluding: "It would be logical to expect that billions of Slovak crowns invested in informatisation will boost IT economy, especially in process of designing and creating of applications in the condition of the Slovak Republic. Seeing things are not quite like this, it testifies to the fact that the strategy of investment in this field is incorrect, financing is chaotic and therefore the process is spontaneous, rather than conceptual." 
education should teach, especially children and youth, how to approach the Internet correctly, how to extract the positive matter that can help improve erudition, cognitive, emotional and social growth in human (Petranová, 2011, p. 68).

\section{Acknowledgment}

This contribution is a partial outcome of the national grant VEGA 1/0284/14 (name of the project: Cyberspace as a new dimension of man, author: prof. PhDr. Slavomír Gálik, PhD., project span: 2014 - 2016).

\section{References}

Bauerlein, M. (2010). Najhlúpejšia generácia. Ako digitálna éra ohlupuje mladých Američanov a ohrozuje našu budúcnost' alebo: never nikomu pod 30. [The dumbest generation: How the digital age stupefies young Americans and jeopardizes our future (Or, don't trust anyone under 30)]. Bratislava: Spolok slovenských spisovatel'ov.

Bell, D. (1973). The Coming of Post-Industrial Society. A Venture in Social Forecasting. New York : Basic Books.

Bystřický, J. et all. (2008). Média, komunikace a kultura. Plzeň : Aleš Čeněk.

Carr, N. (2010). The Shallows. What the Internet is Doing to Our Brain. New York, London: W.W. Norton \& Company Luka.

Cejpek, J. (2005). Informace, komunikace a myšlení. Úvod do informační vědy. Praha : Karolinum.

Deleuze, G., Guattari, F. (2010). Tisíc plošin [Mille Plateaux]. Praha : Herrmann a synové.

Drucker, P. F. (1994). Věk diskontinuity [The Age of Discontinuity]. Praha : Management press.

Eco, U. (2012). Od stromu k labyrintu [Dall'albero al labirinto]. Praha : Argo.

Eriksen, T. H. (2009). Tyranie okamžiku [Tyranny of the moment: Fast and slow time in the information age]. Brno: Doplněk.

Harnad, S. (1991). Post-Gutenberg Galaxy: The Fourth Revolution in the Means of Production of Knowledge. In The Public-Access Computer Systems Review [online ]. 2, no. 1 (1991) [2015-02-10]. pp. 39 - 53.

In <http://cogprints.org/1580/1/harnad91.postgutenberg.html>.

Leidlmair, K. (1999). From the philosophy of technology to a theory of media, p. $13-21$. In PHIL \& TECH Vol 4, n. 3 Spring 1999, [online], [2015-1-26].

In <http://scholar.lib.vt.edu/ejournals/SPT/v4_n3html/LEIDLMAI.html>.

Lohisse, J. (2003). Komunikační systémy. Socioantropologický pohled [Les systèmes de communication. Approche socioanthropologique ]. Praha: Karolinum.

McLuhan, M. (2011). Jak porozumět médím. Extenze člověka [Understanding media: The Extension of man]. Praha: Mladá fronta.

Murgaš, F. (2011). Znalostná ekonomika, tacitné znalosti, spillovers znalosti a ludský kapitál. In RELIK 2011 [online ] [2015-02-10]. p. 1 $-9$.

In<http://kdem.vse.cz/resources/relik11/sbornik/download/pdf/149-Murgas-Frantisek-paper.pdf>.

Petranová, D. (2011). Does media education at schools develop student critical competences?

Communication Today, 2 (1), 66-83.

Potůček, M. at all. (2003). Putování českou budoucností. Praha : Centrum pro sociální a ekonomické strategie, Fakulta sociálních věd UK v Praze.

Pravdová, H. (2009). Determinanty kreovania mediálnej kultúry. Trnava: FMK UCM.

Rankov, P. (2006). Informačná spoločnost' -perspektívy, problémy, paradoxy. Levice: LCA Publishers Group.

Rủžička, M. (1993). Informace a dobro. Praha : Ježek.

Solík, M. (2014). Semiotic approach to analysing of advertising. European Journal of Science and Theology, Vol 10, Suppl. 1, p. 207 217.

Soukup, V. (2004). Dějiny antropologie. Praha: Karolinum.

Spitzer, M. (2014). Digitální demence. Jak prípravujeme sami sebe a naše děti o rozum [Digitale Demenz. Wie wir uns and unsere Kinder um den Verstend bringen]. Brno: Host.

Stratégia informatizácie spoločnosti v podmienkach SR a Akčný plán. (2004). Dokument Vlády SR.

In <file:///C:/Users/fmk/Downloads/Strategia\%20informatizacie\%20spolocnosti\%20v\%20

podmienkach\%20SR.pdf>.

Šándorová, V. (2013). Metódy a formy práce podporujúce kritické myslenie u žiakov zo sociálne znevýhodneného prostredia. Bratislava : Metodicko - pedagogické centrum.

Tökölyová, T., \& Modrzejewski, A. (2013). Role of mass media in foreign policy decision-making. European Journal of Transformation Studies, 1 (2), 37-47.

Višňovský, E. (2014). Idea kreatívnej univerzity: prečo univerzita nie fabrika, biznis ani úrad? In Višňovský, E. a kol.: Univerzita, spoločnost', filozofia: realita verzus hodnoty. Bratislava : Iris, $32-48$. 